\title{
Xanthomonas axonopodis pv. glycines Soybean Cultivar Virulence Specificity Is Determined by avrBs3 Homolog avrXg1
}

\author{
Dusit Athinuwat, Sutruedee Prathuangwong, Luciana Cursino, and Thomas Burr
}

First author: Kasetsart University, Plant Pathology, Faculty of Agriculture; second author: Kasetsart University, Plant Pathology, Faculty of Agriculture; third author: Cornell University-NYSAES, Plant Pathology and Plant-Microbe Biology; and fourth author: Cornell University-NYSAES, Plant Pathology and Plant-Microbe Biology. Accepted for publication 5 April 2009.

\begin{abstract}
Athinuwat, D., Prathuangwong, S., Cursino, L., and Burr, T. 2009. Xanthomonas axonopodis pv. glycines soybean cultivar virulence specificity is determined by avrBs3 homolog avrXg1. Phytopathology 99:9961004.

Three races of Xanthomonas axonopodis pv. glycines were identified on pustule disease resistant and susceptible soybean cultivars based on virulence phenotype. For race 3, an avrBs3 homolog, avrXg1 was

domains of $\operatorname{avrXg1}$ resulted in gained virulence on Williams 82 and an increase in bacterial population number on susceptible cultivars. Expression of $a v r X g 1$ in race 1, that is predicted to confer a nonspecific HR, led to virulence on susceptible cultivars Spencer and PI 520733. Expression of $a v r X g 1$ in race 2, that is predicted of carrying avrBs3-like genes, resulted in gained virulence and fitness of pathogen on both resistant and susceptible cultivars. The results demonstrate multifunctions for $a v r X g 1$ dependent on pathogen and plant genetic backgrounds.
\end{abstract} identified that conferred resistance expressed as a hypersensitive response on resistant cultivar Williams 82. Mutations in two predicted functional
Additional keywords: avirulence gene, bacterial pustule, soybean.
Xanthomonas axonopodis pv. glycines, causes a serious disease, bacterial pustule, on soybean that results in reduced yield and crop quality (31). Virulence of $X$. axonopodis pv. glycines is associated with different genetic determinants, including a pathogenicity island that includes nine $h r p$, nine $h r c$, and eight hpa genes that are regulated by HrpG and HrpX. This cluster includes genes composing a type III secretion system (TTSS) that is essential for pathogenesis and for induction of a hypersensitive reaction (HR) on some plant species (30). The HrpG effector was shown to be essential for induction of a nonspecific HR on different nonhost plants (27). Mutation of HrpG demonstrated that it plays critical roles in HR on tobacco (26). Recently, another gene, $x a g P$, that encodes a pectate lyase in $X$. axonopodis pv. glycines, was also shown to be essential for induction of HR on tobacco and pepper but not on cucumber, sesame, and tomato (20). Together, these studies demonstrated that $X$. axonopodis pv. glycines possesses several genes that are associated with induction of disease and HR.

Several plant-pathogenic bacteria express host-specific virulence that is often confined to members of a single plant species or cultivar. Such scenarios often involve avirulence (avr) genes encoding proteins that react with specific resistance $(R)$ receptors, produced in plants leading to reduced pathogen growth and plant cell death (HR). The interaction between Avr proteins and $R$-gene receptors was first described in the wellknown gene-for-gene hypothesis (10). It has also been shown that $a v r$ genes may contribute to pathogen aggressiveness $(4,24)$ and, in some cases, inhibit development of nonspecific HR $(2,8,11$, $33,47)$.

Corresponding author: T. Burr; E-mail address: tjb1@cornell.edu

* The $\boldsymbol{e}$-Xtra logo stands for "electronic extra" and indicates that Figure 1 appears in color online.

doi:10.1094/PHYTO-99-8-0996

(C) 2009 The American Phytopathological Society
In contrast to the dominant Avr-R incompatible HR, a compatible reaction (where Avr or R proteins are not present) results with the pathogen multiplying for a prolonged time period, development of water-soaked lesions, and, subsequently, infected tissue that becomes necrotic and dies (41). Avirulence and other effector proteins are transported via the TTSS across the bacterial membrane and into plant cells $(3,5)$. Bacterial $a v r$ genes were characterized into two groups: group 1 includes members of the avrBs3/pthA (avirulence and pathogenicity) family from $X$. axonopodis pv. vesicatoria and group 2 from Pseudomonas syringae, $X$. campestris, and Ralstonia solanacearum (47).

Members of the avrBs3/pthA family have unique structural features, including repeats of $102 \mathrm{bp}$ in their central portion, three nuclear localization signals (NLSs), and an acidic activation domain (AAD) in the C-terminal region (34). Some Xanthomonas spp. contain multiple homologs of avrBs3/pthA. For example, in $X$. axonopodis pv. malvacearum, multiple avrBs3/pthA genes contribute additively to the water soaking on cotton $(39,52)$. $X$. axonopodis pv. vesicatoria carries avrBs 3 and avrBs4 that affect HR and disease on different pepper cultivars (7). X. axonopodis pv. citri (Hasse) (46) also contains at least three avrBs3/pthA homologs (21) and all strains of $X$. oryzae pv. oryzae contain more than 15 avrBs3/pthA homologs, which are major pathogenicity genes required for full virulence in rice (51). Recently, in $X$. axonopodis pv. glycines, two plasmids, pAG1 and pXAG81, were found to carry avrBs3 gene homologs but their possible roles in HR and disease were not determined $(25,40)$.

$R$ gene clusters within soybean associated with pustule disease resistance have also been identified (22). The resistance gene $r x$ for bacterial pustule was originally identified in resistance cultivar CNS and subsequently transferred to other commercial cultivars, including Williams 82 (22); cultivars carrying the Rxp allele are susceptible (44).

In this study, we describe races of $X$. axonopodis pv. glycines from Thailand that express differential virulence on soybean cultivars that is determined by the presence of an $a v r$ gene. A new member of the avrBs3/pthA family is described that, when intro- 
duced to race 1 and 2 of $X$. axonopodis pv. glycines, confers a virulence phenotype and additive fitness of pathogen on normally resistant and susceptible soybean cultivars.

\section{MATERIALS AND METHODS}

Bacterial strains, plasmids, and recombinant techniques. Strains of $X$. axonopodis pv. glycines and Escherichia coli and plasmids used in this study are listed in Table 1 . X. axonopodis pv. glycines strains were initially isolated and characterized from infected soybean plants collected in various Thai provinces by Saiseangthong (35). All strains were shown to cause pustule disease on soybean cv. SJ4. They were cultured in nutrient glu- cose agar (NGA) or nutrient yeast extract (NBY) agar (49) at $28^{\circ} \mathrm{C}$. E. coli, used as the cloning host, was cultured in LuriaBertani (LB) agar at $37^{\circ} \mathrm{C}$. Antibiotics were added to media at the following concentrations: ampicillin, $100 \mu \mathrm{g} / \mathrm{ml}$; kanamycin, 15 or $50 \mu \mathrm{g} / \mathrm{ml}$; and gentamicin, 25 or $40 \mu \mathrm{g} / \mathrm{ml}$. All DNA manipulations, including the DNA isolation, plasmid extractions, restriction digests, ligations, and gel electrophoresis, were performed as described previously (36).

Race-cultivar specificity. Thirty-four strains of $X$. axonopodis pv. glycines were evaluated for pathogenicity on 15-day-old soybean cultivars, including Williams 82 (resistant), Spencer (susceptible), and PI 520733 (susceptible) $(13,17,22)$. A leaf infiltration technique under greenhouse conditions was used to assess

TABLE 1. Bacterial strains and plasmids

\begin{tabular}{|c|c|c|}
\hline Bacterial strain or plasmidy & Relevant characteristic ${ }^{\mathrm{z}}$ & $\begin{array}{l}\text { Reference or source } \\
\text { (Thai province) }\end{array}$ \\
\hline Escherichia coli TOP10 & lacZ $\Delta \mathrm{M} 15$, endA1, recA1, $h s d \mathrm{R}, \mathrm{mcrA}$ & Invitrogen \\
\hline E. coli JM109 & 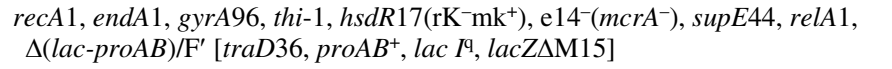 & Promega \\
\hline E. coli TOP10 (pUC19-AVR) & E. coli TOP10 carrying pUC19-AVR & This study \\
\hline E. coli TOP10 (pBBR-AVR) & E. coli TOP10 carrying pBBR-AVR & This study \\
\hline E. coli $\mathrm{DH} 5 \alpha$ & 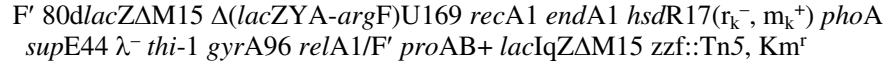 & Invitrogen \\
\hline KU-P-34008 & Race 2 & Chiang Mai \\
\hline KU-P-34009 & Race 1 & Khonkaen \\
\hline KU-P-34016 & Race 2 & Chainat \\
\hline KU-P-34016a & Race 1 & Uttaradit \\
\hline KU-P-34017 & Race 1 & Nakhon Sawan \\
\hline KU-P-34021 & Race 1 & Nakhon Ratchasima \\
\hline KU-P-34028 & Race 1 & Lop Buri \\
\hline KU-P-34054 & Race 1 & Phrae \\
\hline KU-P-34062 & Race 1 & Chiang Rai \\
\hline KU-P-34064 & Race 1 & Sukhothai \\
\hline KU-P-34069 & Race 1 & Tusanasarit (43) \\
\hline KU-P-34071 & Race 1 & Loei \\
\hline KU-P-34072 & Race 1 & Tusanasarit (43) \\
\hline KU-P-34075 & Race 1 & Prachin Buri \\
\hline KU-P-34083 & Race 1 & Tak \\
\hline KU-P-34085 & Race 1 & Khonkaen \\
\hline KU-P-34089 & Race 2 & Phitsanulok \\
\hline KU-P-34093 & Race 1 & Tusanasarit (43) \\
\hline KU-P-34096 & Race 1 & Kamphaeng Phet \\
\hline KU-P-34098 & Race 2 & Loei \\
\hline KU-P-34070 & Race 1 & Sukhothai \\
\hline KU-P-34070 (pBBR-AVR) & Race 1 transformed with avrXg1 & This study \\
\hline KU-P-KPS06 & Race 2 & Nakhon Prathom \\
\hline KU-P-KPS06 (pBBR-AVR) & Race 2 transformed with avrXgl & This study \\
\hline \multicolumn{3}{|l|}{ Plasmids } \\
\hline pBBR1MCS-5 & Broad host range cloning vector, $l a c Z, \mathrm{Gm}^{\mathrm{r}}$ & Kovach et al. (28) \\
\hline pUC19 & ColE1; lacZ Amp ${ }^{\mathrm{r}}$ & Promega \\
\hline pGEM-T easy & Polymerase chain reaction cloning vector, $\operatorname{lac} Z, \mathrm{Amp}^{\mathrm{r}}$ & Promega \\
\hline pUC19-AVR & $\begin{array}{l}\text { 5-kb avrXg1 fragment from KU-P-SW005 carrying Tn5 insertion cloned in } \\
\text { pUC19, } \mathrm{Km}^{\mathrm{r}} \mathrm{Amp}^{\mathrm{r}}\end{array}$ & This study \\
\hline pBBR-AVR & 3.8-kb Sequence of $a v r X g 1$ in the pBBR1MCS-5, $\mathrm{Km}^{\mathrm{r}} \mathrm{Gm}^{\mathrm{r}}$ & This study \\
\hline
\end{tabular}

${ }^{y} \mathrm{ADD}$, acidic activation domain; REP, central repeat region.

${ }^{\mathrm{z}} \mathrm{Km}^{\mathrm{r}}, \mathrm{Amp}^{\mathrm{r}}$, and $\mathrm{Gm}^{\mathrm{r}}$ indicate resistance to kanamycin, ampicillin, and gentamicin, respectively. 
virulence on soybean leaves. Infiltrations were done in a completely randomized design. Bacterial suspensions (50 $\mu \mathrm{l}$, optical density at $600 \mathrm{~nm}\left[\mathrm{OD}_{600}\right]=0.2, \approx 10^{8} \mathrm{CFU} / \mathrm{ml}$ ) were infiltrated into the leaf mesophyl through a pin puncture with a 1-ml syringe without a needle. Nine leaves on different plants were inoculated for each strain. Infiltration assays were monitored for their ability to cause HR (necrosis) or disease (spreading infection with yellow halo) $48 \mathrm{~h}$ post inoculation. The experiment was repeated three times.

Transposon mutagenesis. Random mutagenesis of wild-type race 3 strain KU-P-SW005 was performed as described previously by Kaewnum and associates (20). Briefly, $1 \mu \mathrm{l}$ of EZ-Tn5 $<$ KAN-2 $>$ Tnp Transposome (Epicentre, WI) was added to $50 \mu \mathrm{l}$ of electrocompetent cells and $0.5 \mu \mathrm{l}$ of TypeOne restriction inhibitor (Epicentre); mixtures were placed in a $0.25-\mathrm{cm}$ electroporation cuvette on ice. The cells were electroporated with a BioRad GenePluser Xcell electroporation system (Hercules, CA) at $2.5 \mathrm{kV}, 25 \mu \mathrm{F}$, and $200 \Omega$ and were then added to fresh $1 \mathrm{ml}$ of NBY broth and incubated at $28^{\circ} \mathrm{C}$ for $1 \mathrm{~h}$. Cells were then plated on NBY medium supplemented with kanamycin. Resistant clones were screened for ability to cause HR and disease on the soybean cultivars as described above and were subsequently verified for Tn5 insertion by polymerase chain reaction (PCR).

Total DNA of Tn5 mutant KU-P-SW005 avrXg1::Tn5AAD, which gained virulence function on soybean cv. Williams 82, was extracted, partially digested with EcoRI and SacI (no restriction site in transposon), cloned into pUC19 (Promega Corp., Madison, WI) and transformed by heat shock into E. coli DH5 $\alpha$ (Invitrogen, CA). Clones were selected on LB agar amended with kanamycin and ampicillin and verified by PCR amplification of an 800-bp product using the EZ-Tn5 derived primers KAN-1-FP and KAN-1-RP (Table 2). Sequences of clones carrying EZ-Tn5 transposon were identified by PCR amplification with M13F and M13R universal primers.

Genomic sequences flanking the EZ-Tn5 transposon insertions in KU-P-SW005 avrXg1::Tn5AAD were identified by PCR amplification of the disrupted gene with primers KAN-2-FP and KAN-2-RP (Epicentre). DNA sequencing was done at the Cornell Life Sciences Core Laboratories Center.

Site-directed mutagenesis. A targeted mutation in the avrBs3 homolog in KU-P-SW005 was accomplished using the EZ-Tn5 $<\mathrm{KAN}-2>$ Insertion Kit (Epicentre) according to the supplier's directions. First, a 3.8-kb fragment was amplified from KU-PSW005 using primers AVR-FP and AVR-RP that were based on the sequence of the avrBs3 homolog (AY780632.1) previously identified in X. axonopodis pv. glycines strain AG1 (25).

The 3.8-kb fragment containing the coding region of the avrBs 3 homolog was cloned into pGEM-T easy vector (Promega Corp.) and digested with EcoRI (no restriction site in avrBs3 homolog gene), and the target fragment was ligated into pUC19. Subsequently, a Tn5 targeted insertion in the gene was made in vitro following the supplier's directions. Briefly, $1 \mu \mathrm{l}$ of pUC19 DNA containing the avrBs3 homolog was mixed with $0.5 \mu \mathrm{l}$ of EZ-Tn5 <KAN-2> transposon, $1 \mu$ l of EZ-Tn5 $10 \times$ reaction buffer, $1 \mu \mathrm{l}$ of EZ-Tn5 transposase, and $6.5 \mu \mathrm{l}$ of sterile water; the mixture was transformed by heat shock into $E$. coli TOP10 (Invitrogen). Clones were selected on LB agar amended with kanamycin and ampicillin. Selection of plasmid pUC19-AVR carrying a single Tn5 insertion in the middle of the target gene was shown by digestion with EcoRI and separation by gel electrophoresis. Confirmation of the pUC19-AVR construct was by PCR with primers AVR-FP and AVR-RP. Sequencing of pUC19-AVR was done at the Cornell Life Sciences Core Laboratories Center.

Transformation into KU-P-SW005 was performed by electroporation as described above. Briefly, $2 \mu \mathrm{l}$ of pUC19-AVR and $0.5 \mu \mathrm{l}$ of TypeOne restriction inhibitor were added to $50 \mu \mathrm{l}$ of $\mathrm{KU}$ P-SW005 electrocompetent cells and subjected to electroporation in a $0.25-\mathrm{cm}$ cuvette at $2.5 \mathrm{kV}, 25 \mu \mathrm{F}$, and $200 \Omega$. Electroporated cells were added to fresh NBY broth and incubated at $28^{\circ} \mathrm{C}$ for $1 \mathrm{~h}$. Transformants were selected on NBY agar containing appropriate antibiotics. Resistant clones were screened for ability to cause HR and disease on the soybean cultivars as described above and were subsequently verified for Tn5 insertion by PCR.

Presence of the avrBs3 homolog in $X$. axonopodis $p v$. glycines races. All 34 strains were evaluated for the presence of the avrBs3 3.8-kb region amplified by primers AVR-FP and AVRRP (Table 2). PCR products were separated by gel electrophoresis. The presence of the PCR product was correlated with strain-cultivar pathogenicity reactions.

Sequencing and evaluation. The $3.8-\mathrm{kb}$ region amplified from KU-P-SW005 was cloned into the pGEM-T easy vector. Primer walking and PCR were employed for amplification and sequencing of the entire gene. All primer sequences are listed in Table 2. The PCR products were cloned into pGEM-T easy vector. DNA sequencing was done as described above. Analysis of sequences was conducted using BLAST and the DNASTAR Lasergene software package (DNAstar, Inc., Wl). The MegAlign program of the DNASTAR package was used for sequence alignment using CLUSTALW. MegAlignment was then calculated for the $a v r$ gene sequences as available from GenBank for selected Xanthomonas spp. EMBOSS Transeq, ScanSite $\mathrm{pI} / \mathrm{Mw}$, and BPROM were used to translate DNA to deduced proteins, compute the theoretical isoelectric point (pI) and molecular weight (Mw) of proteins, and for prediction of bacterial promoters, respectively.

Nucleotide sequence accession number. The complete DNA sequence of the gene obtained from $X$. axonopodis pv. glycines

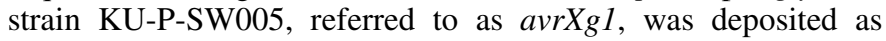
GenBank accession no. FJ439173.

Transformation of mutants and race 1 with avrXg1. To complement KU-P-SW005 avrXg1::Tn5AAD and KU-P-SW005 avrXgl::Tn5REP, the $3.8-\mathrm{kb}$ sequence comprising avrXgl in

TABLE 2. Polymerase chain reaction primers

\begin{tabular}{lll}
\hline Primer & \multicolumn{1}{c}{ Sequence } & \multicolumn{1}{c}{ Description } \\
\hline AVR-FP & 5' ATG GAT CCC ATT CGT TCG 3' & Amplification of 3.8-kb of $a v r B s 3$ gene family \\
AVR-RP & 5' TCA CTG AGG CAA TAG CTC CA 3' & $\ldots$ \\
AVR-1-FP & 5' AAT ATT GGC GGC AAG CAG GC 3' & Amplification of 863-bp fragment of $a v r X g 1$ \\
AVR-1-RP & 5' CGC CTG CTT GCC ACC AAT ATT 3' & $\ldots$ \\
AVR-2-FP & 5' AAT ATT GGT GGC AAG CAG GCG 3' & Amplification of 1.0-kb fragment of $a v r X g 1$ \\
AVR-2-RP & 5' TTG CCA CCA ATA TTG CTG GCG AT 3' & $\ldots$ \\
AVR-3-FP & 5' AGC CAC TTG TAG AAC GTG 3' & Amplification of 4.1-kb avrBs 3 homolog and flanking sequences \\
AVR-3-RP & 5' GCT AAC TCG CTG TCA GTA 3' & $\ldots$ \\
KAN-1-FP & 5' AAG CC GAT GCG CCA GAG TT 3' & Amplification of kanamycin gene (800 bp) \\
KAN-1-RP & 5' CGC CGT CCC GTC AAG TCA G 3' & $\ldots$ \\
KAN-2-FP & 5' ACC TAC AAC AAA GCT CTC ATC AAC C 3' & For sequencing \\
KAN-2-RP & 5' GCA ATG TAA CAT CAG AGA TTT TGA G 3' & $\ldots$ \\
M13F & 5' TGT AAA ACG ACG GCC AGT 3' & Universal primers \\
M13R & 5' AAC AGC TAT GAC CAT G 3' & $\ldots$ \\
\hline
\end{tabular}


pGEM-T easy vector was digested with EcoRI and ligated into the multiple cloning site vector pBBR1MCS-5 (pBBR-AVR). Plasmid pBBR-AVR was introduced into mutants KU-P-SW005 avrXg1::Tn5AAD, KU-P-SW005 avrXg1::Tn5REP, wild-type race 1 KU-P-34070, and wild-type race 2 KU-P-KPS06 by electroporation according to the method described above. Selections were made on NBY, with appropriate antibiotics. Clones were verified by PCR and evaluated for their ability to cause HR on Williams 82 and disease on Spencer and PI 520733.

Virulence and bacterial growth on soybean. Virulence of KU-P-SW005, KU-P-SW005 avrXg $1:: T n 5 A A D$, KU-P-SW005 avrXg1::Tn5REP, avrXg1::Tn5AAD (pBBR-AVR), avrXg1:: Tn5REP (pBBR-AVR), KU-P-34070, KU-P-34070 (pBBR-AVR), KU-P-KPS06, and KU-P-KPS06 (pBBR-AVR) were assessed on soybean cvs. Spencer and Williams 82, using previously described quantitative methods (19). Briefly, aqueous cell suspensions $\left(\mathrm{OD}_{600}=0.2, \approx 10^{8} \mathrm{CFU} / \mathrm{ml}\right.$ of each) were sprayed on leaves of plants maintained in the greenhouse. At 7 to 10 days after inoculation, disease severity was assessed using a scoring method (32) based on the number of sections having at least one pustule observed in nine $1-\mathrm{cm}^{2}$ diameter sections per leaf. Three trifoliate leaves, collected from the top, middle, and basal portion of three plants, were evaluated for each strain.

Bacterial growth was also assessed within the infiltrated zone. Leaf discs, $5 \mathrm{~mm}$ in diameter, were cut from the center of the infiltrated zone at 1, 2, 3, and 4 days post infiltration (three discs for each times). Samples were placed individually in $1 \mathrm{ml}$ of sterile water and triturated, and dilutions were plated on NGA. Leaf surface inoculation and infiltration experiments were repeated three times. The results were statistically analyzed using SAS (version 9.1.2; SAS Institute Inc., Cary, NC).

Genome location of avrXg1. Total genomic and plasmid DNA of KU-P-SW005, KU-P-SW005 avrXg1::Tn5AAD, KU-PSW005 avrXg1::Tn5REP, and KU-P-34070 were extracted by UltraClean Microbial DNA Isolation Kit Components and UltraClean 6 Minute Mini Plasmid Prep Kit (MO BIO, CA), respectively. The plasmid DNAs were size fractionated on a lowmelting agarose gel. Purified fragments of 15 to $30 \mathrm{~kb}$ were used as the PCR template. KAN-1-FP and KAN-1-RP primers were used to amplify an 800-bp product, including the kanamycin resistance marker from the total genomic and plasmid DNA. PCR products were separated by gel electrophoresis.

The genome location of $a v r X g l$ was analyzed further by PCR amplification of regions flanking the gene (274 bp upstream and 70 bp downstream) with primers AVR-3-FP and AVR-3-RP (Table 2 ). PCR products were cloned in pGEM-T easy vector. DNA sequence was identified by PCR amplification of the avrXgl fragment with primers AVR-3-FP and AVR-3-RP and with M13F and M13R universal primers.

\section{RESULTS}

Race-cultivar specificity. Three races of $X$. axonopodis pv. glycines were identified from strains collected in Thailand based on their ability to cause disease or an HR on three soybean cultivars. Race 1 (23 strains) induced HR within $48 \mathrm{~h}$ and Race 2 (7 strains) caused disease on all three cultivars. Race 3 (four strains) elicited HR on the resistant cultivar (Williams 82) and caused pustule disease on pustule-susceptible cvs. Spencer and PI 520733 (Table 1; Fig. 1). The HR was visualized as a localized necrosis in the leaf infiltration zone whereas disease was expressed as necrosis with a surrounding yellow halo. Characteristic pustules developed beyond the infiltration zone 7 days after inoculation (not shown).

Screening and characterization of mutants. Of 3,336 random Tn5 mutants generated from strain KU-P-SW005, 1, designated KU-P-SW005 avrXg1::Tn5AAD (Tn5 insertion in putative AAD domain of AvrXg1), caused disease on all three soybean cultivars, including Williams 82 (wild-type causes HR). Therefore, it was hypothesized that an avirulence factor was knocked out, making the mutant virulent on Williams 82. The region surrounding the Tn5 insertion in KU-P-SW005 avrXg1::Tn5AAD was sequenced and showed identity (100\% at nucleotide level) within a deduced ADD domain in the C-terminal region of an avrBs3 gene homolog in $X$. axonopodis pv. glycines strains AG1 and 8ra (AY780631.1 and AY780632.1, respectively) (25), X. axonopodis pv. malvacearum (L06634.1), X. axonopodis pv. vesicatoria (X68781.1 and X16130.1), and $X$. axonopodis pv. citri (AB021365.1, AB206389.1, AB206387.1, U28802.1, AE008925.1, AE008924.1, AB021363.1, AB021364.1, and AB175482.1). This

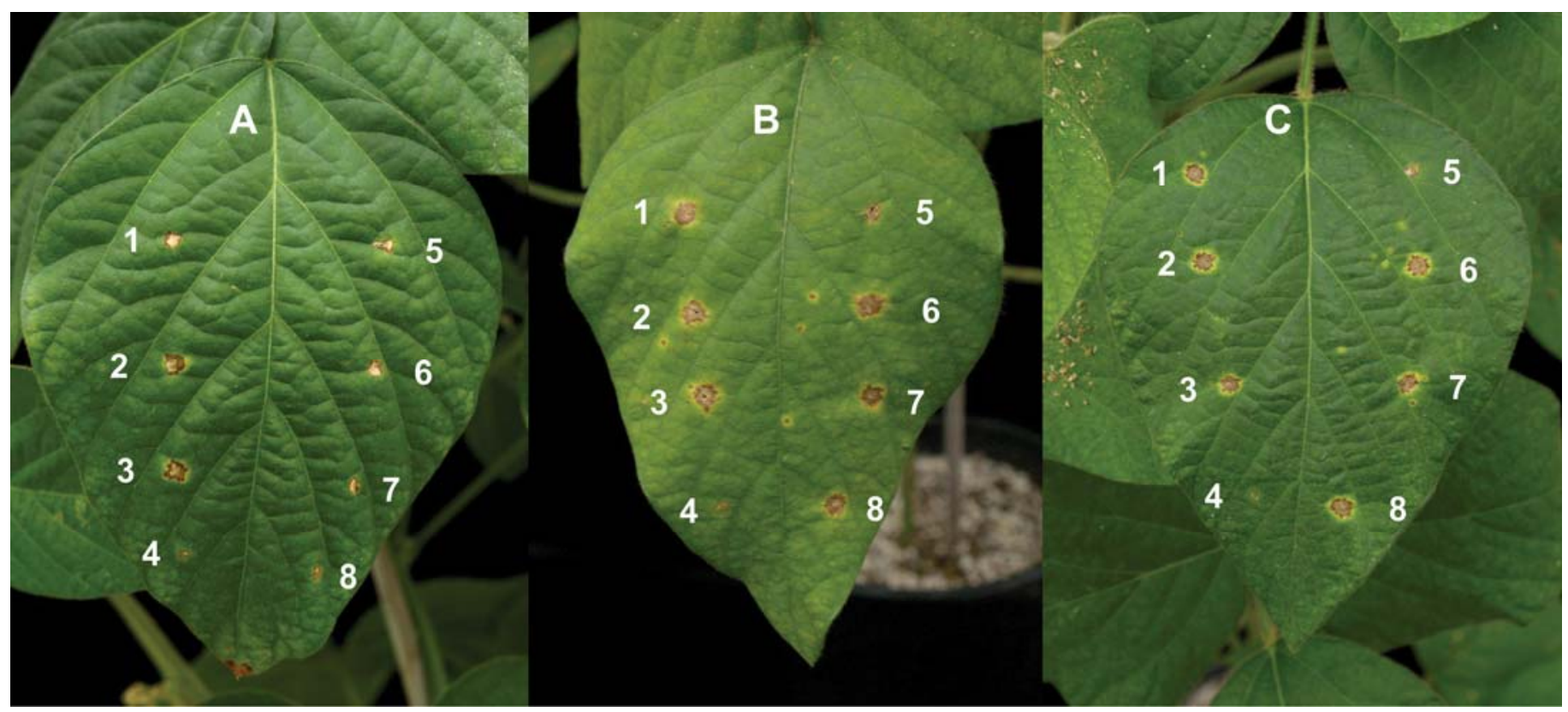

Fig. 1. Comparison of compatible and incompatible reactions on soybean cvs. A, Williams 82; B, Spencer; and C, PI 520733 following leaf infiltration with KUP-SW005 (1), KU-P-SW005 avrXg1::Tn5AAD (2), KU-P-SW005 avrXg1::Tn5REP (3), Escherichia coli TOP10 (pBBR-AVR) (4), race 1 KU-P-34070 (5), complemented mutant $a v r X g 1::$ Tn5AAD (pBBR-AVR) (6), and avrXg1::Tn5REP (pBBR-AVR) (7), and KU-P-34070 (pBBR-AVR) (8). Bacteria were infiltrated into soybean leaves as described in text. Symptoms were recorded 7 days after infiltration. 
strongly suggested that the gene mutated was a member of the avrBs3 gene family that hereafter is referred to as $a v r X g 1$.

To confirm that the virulence phenotype observed on Williams 82 resulted from disruption of $a v r X g 1$, a targeted mutation was made at the fourth repeat region within the central portion of the gene. The resulting mutant, KU-P-SW005 avrXgl::Tn5REP, displayed the same phenotypes as KU-P-SW005 avrXg1::Tn5AAD (Fig. 1).

Presence of avrBs3-like genes in races of $X$. axonopodis pv. glycines. Further characterization of $X$. axonopodis pv. glycines races was accomplished by PCR analyses of genomic DNA with primers AVR-FP and AVR-RP. A 3.8-kb product was detected in races 2 and 3 but not in race 1 strains (not shown). These results suggest that the nonspecific HR phenotype of race 1 is not associated with an avrBs3-like gene but is associated with a different mechanism of HR. The detection of the amplicon in race 2 strains demonstrates the presence of one or more genes in the avrBs3/pthA family but not the presence of $a v r X g 1$ specifically.

Analyses of avrXg1. The complete sequence of $\operatorname{avrXgl}$ was compared with the avrBs 3 homolog in $X$. axonopodis pv. glycines strain AG1 (AY780631.1) (25). The coding region of avrXgl gene is $3.8 \mathrm{~kb}$ in length, with an overall $\mathrm{G}+\mathrm{C}$ content of $67 \%$. The central region of the gene was characterized by 20.5 copies of tandemly arranged 102-bp direct repeats. The C-terminal region of the gene was defined by three NLSs and an AAD domain (Fig. 2 ), characteristic of other sequenced members of the avrBs3/pthA gene family.

Alignment analysis of $a v r X g 1$ by MegAlign program (DNAstar, Inc.) revealed that the deduced protein shares identity with AvrBs3-like protein sequences (98\% at amino acid levels) of X. axonopodis pv. glycines strain AG1 and 8ra (YP_001965982.1 and YP_001966011.1, respectively) and encodes a predicted 1,266 -amino-acid protein with a molecular mass of $132.8 \mathrm{kDa}$ and $\mathrm{pI}$ of 8.8. The amino acid sequence of the deduced protein from $a v r X g 1$ showed differences in 13 amino acid residues in the $\mathrm{N}$-terminal region at positions $23,76,81,82,85,89,91,92,94$, $95,130,134$, and 197 compared with the avrBs3 homologs from AG1 and 8ra (YP_001965982.1 and YP_001966011.1, respectively) (25). The putative start codon of $a v r X g 1$ is ATG, and predicted promoter positions, -35 and -10 boxes, are located at position 171 and 190, -TTGCCA- and -TTGTGTACT-, respectively, upstream from the start codon. A signal peptide, MDPIRSRTPSPARELLPGPQPDRVQPTADR, is also predicted for AvrXg1.

Complementation and virulence assays on soybean. Complementation of KU-P-SW005 avrXg1::Tn5AAD and KU-PSW005 avrXg $1:: \operatorname{Tn} 5$ REP were accomplished by transformation with pBBR-AVR. This resulted in regained ability to induce a strong HR on Williams 82 and pustule disease on Spencer and PI 520733 within $48 \mathrm{~h}$ and 5 days after infiltration, respectively. $E$. coli TOP10 harboring pBBR-AVR did not cause HR or disease on Williams 82, Spencer, or PI 520733. Lesion expansion of KU-PSW005, KU-P-SW005 avrXg1::Tn5AAD, KU-P-SW005 avrXg1::Tn5REP, avrXg1::Tn5AAD (pBBR-AVR), and avrXg1:: Tn5REP (pBBR-AVR) on Williams 82 and Spencer did not differ (Table 3 ). However, virulence of strains refers to disease severity rather than lesions size.

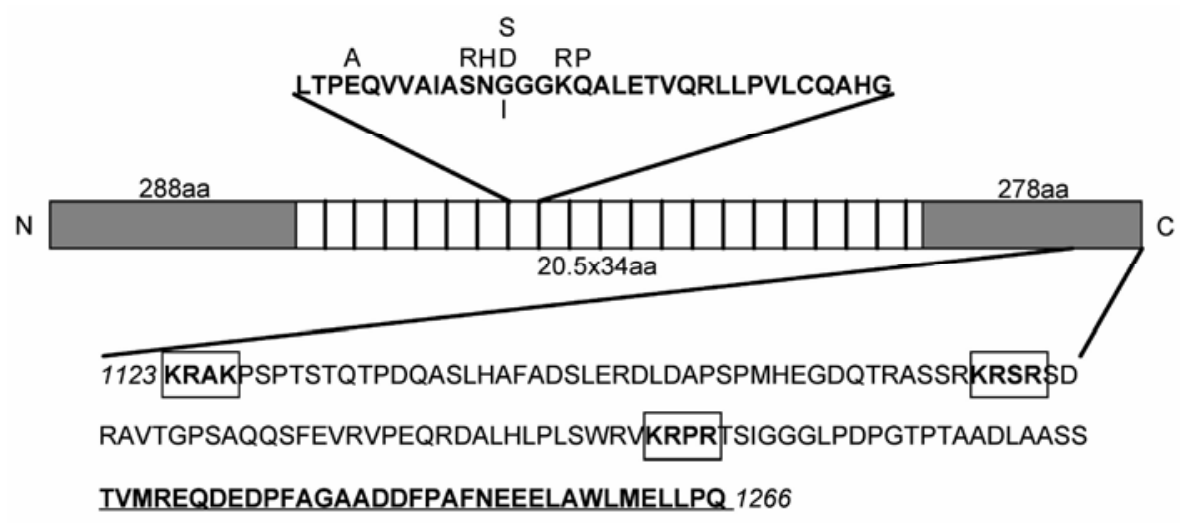

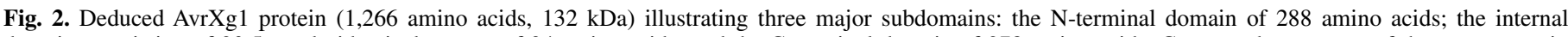

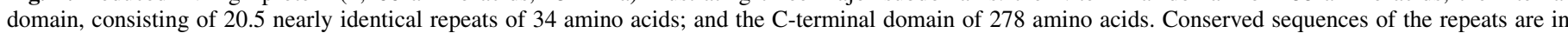

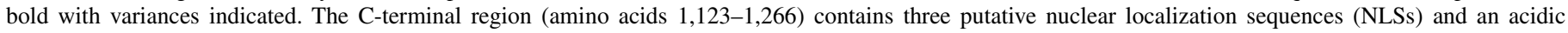

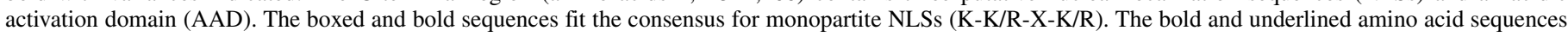
indicate the proposed AAD.

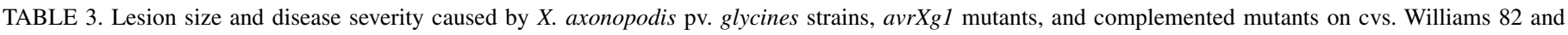
Spencer $^{\mathrm{X}}$

\begin{tabular}{|c|c|c|c|c|}
\hline \multirow[b]{2}{*}{ Strain $^{y}$} & \multicolumn{2}{|c|}{ Lesion mean diameter (mm) } & \multicolumn{2}{|c|}{ Disease severity $(\%)^{\mathrm{z}}$} \\
\hline & Williams 82 & Spencer & Williams 82 & Spencer \\
\hline KU-P-SW005 & HR & $0.65 \mathrm{a}$ & HR & $29.62 \mathrm{~b}$ \\
\hline KU-P-SW005 avrXg1::Tn5AAD & $0.65 \mathrm{a}$ & $0.64 \mathrm{a}$ & $11.11 \mathrm{~b}$ & $51.02 \mathrm{a}$ \\
\hline avrXg1::Tn5AAD (pBBR-AVR) & HR & $0.64 \mathrm{a}$ & HR & $26.33 \mathrm{~b}$ \\
\hline KU-P-SW005 avrXg $1::$ Tn5REP & $0.66 \mathrm{a}$ & $0.65 \mathrm{a}$ & $12.34 \mathrm{~b}$ & $49.79 \mathrm{a}$ \\
\hline avrXg1::Tn5REP (pBBR-AVR) & HR & $0.63 \mathrm{a}$ & HR & $25.51 \mathrm{~b}$ \\
\hline KU-P-34070 & HR & HR & HR & HR \\
\hline KU-P-34070 (pBBR-AVR) & HR & $0.52 \mathrm{~b}$ & HR & $23.86 \mathrm{~b}$ \\
\hline KU-P-KPS06 & $0.65 \mathrm{a}$ & $0.66 \mathrm{a}$ & $53.50 \mathrm{a}$ & $54.73 \mathrm{a}$ \\
\hline KU-P-KPS06 (pBBR-AVR) & $0.67 \mathrm{a}$ & $0.67 \mathrm{a}$ & $57.61 \mathrm{a}$ & $58.01 \mathrm{a}$ \\
\hline
\end{tabular}

x Numbers followed by different letters show significance at $P \leq 0.05$. HR $=$ hypersensitive response.

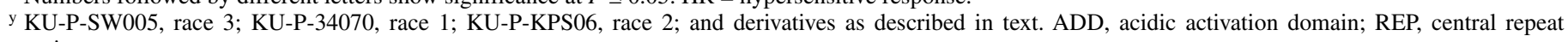
region.

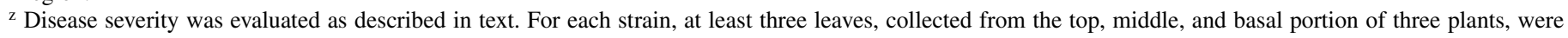
evaluated. 
Function of $a v r X g l$ was further verified by expression of the gene in race 1 strain KU-P-34070 transformed with pBBR-AVR, resulting in HR on Williams 82 within $48 \mathrm{~h}$ and disease on Spencer and PI 520733 within 5 days after infiltration. The surrounding yellow halo caused by transformed KU-P-34070 on the susceptible cultivars, however, appeared smaller than for wildtype race 3 KU-P-SW005 (Table 3). These results suggest that avrXgl in the race 3 genetic background blocks expression of the nonspecific HR on susceptible cultivars.

Wild-type race 2 strain KU-P-KPS06 was also transformed with pBBR-AVR, resulting in more rapid and increased disease on Williams 82 and Spencer (i.e., disease observed in 3 days compared with 5 days for wild-type). Lesion expansion of KU-PSW005, KU-P-KPS06, and KU-P-KPS06 (pBBR-AVR) on Williams 82 and Spencer did not differ (Table 3). These results suggest that $a v r X g l$ can also induce gain of virulence on soybean.

Mutants KU-P-SW005 avrXg1::Tn5AAD, and KU-P-SW005 avrXg1::Tn5REP; wild-type race 2 KU-P-KPS06; and transformed race 2 KU-P-KPS06 (pBBR-AVR) gave the highest virulence ratings on Spencer and Williams 82 (Table 3). In contrast, wild-type race 3 KU-P-SW005, complemented strains avrXg1:: Tn5AAD (pBBR-AVR) and $\operatorname{avrXg1::Tn5REP~(pBBR-AVR),~and~}$ transformed race 1 KU-P-34070 (pBBR-AVR) gave disease severities on Spencer that were lower than both mutants and wildtype race 2 (Table 3 ).

Growth of mutants KU-P-SW005 avrXg1::Tn5AAD, KU-PSW005 avrXg1::Tn5REP, and KU-P-KPS06 (pBBR-AVR) in Spencer and Williams 82 tissue were significantly increased $(P \leq$ $0.05)$, reaching population numbers higher than wild-type strains (Fig. 3). Furthermore, KU-P-34070 (pBBR-AVR) grew in leaves and induced the disease on susceptible cultivars, whereas wildtype KU-P-34070 caused HR and was not detected on Spencer. These results suggest that the central repeat and AAD regions are associated with the ability of AvrXg1 to confer both additive fitness and redundancy of virulence functions.

Viable cells of KU-P-SW005, avrXg1::Tn5AAD (pBBR-AVR), avrXg1::Tn5REP (pBBR-AVR), KU-P-34070, and KU-P-34070 (pBBR-AVR) were not detected in the HR-expressing tissues of Williams 82 leaves $48 \mathrm{~h}$ after.

Location of avrXg1 in KU-P-SW005 genome. It was determined that KU-P-SW005 carries 26-, 15-, and 1.3-kb native plasmids, whereas race 1 strain KU-P-34070 does not have the 26and 15-kb plasmids (not shown). The sequence of three native plasmids pAG1, pXAG81, and pXAG82 of sizes 26, 15, and $1.3 \mathrm{~kb}$, respectively, were previously reported in $X$. axonopodis pv. glycines strains AG1 and 8ra, and only pAG1 and pXAG81 contained avrBs3 homologs (AY780631.1 and AY780632.1 respectively) (25).

For mutants KU-P-SW005 avrXg1::Tn5AAD and KU-PSW005 avrXg1::Tn5REP, total genomic and plasmid DNAs were examined for the presence of the 800-bp kanamycin resistance marker. The amplicon was detected on both templates of mutants, providing evidence that $a v r X g l$ is located on the native plasmid of KU-P-SW005. Moreover, DNA sequencing of the putative coding region 274 bp upstream and $70 \mathrm{bp}$ downstream of $a v r X g 1$ from plasmid DNA of KU-P-SW005 avrXg1::Tn5AAD and KUP-SW005 avrXg1::Tn5REP showed identity (100\% at nucleotide level) to regions upstream and downstream of an $a v r B s 3$ homolog located on pAG1 (25), again indicating that $a v r X g 1$ is plasmidborne.

\section{DISCUSSION}

Recent research has significantly advanced our understanding of the heterogeneity of $X$. axonopodis pv. glycines and how it interacts with different plant species $(19,27)$. Race structure of $X$. axonopodis pv. glycines from the United States was initially determined based on reactions on five soybean cultivars with
Williams 82 determined to be resistant to all five races (17). Recently, Park et al. (29) characterized X. axonopodis pv. glycines strains from Korea into six groups based on the predicted number of copies of $a v r B s 3$-like genes within each strain. When strains were probed with a $3.6-\mathrm{kb}$ internal fragment of an avrBs3 homolog, three to eight copies of the gene were detected in digests of total genomic and plasmid DNA, suggesting the presence of multiple copies of avrBs3-like genes. However, pathogenicity of representative strains from each group did not show specificity to soybean cultivars. Previous work also demonstrated the presence of an $a v r B s 3$ homolog carried on plasmids in Korean strains of $X$. axonopodis pv. glycines (25). It was shown that $X$. axonopodis pv. glycines strains from pustule-infected soybean leaves carried one of two related plasmids that include an avrBs3 homolog. Function for the putative gene, however, was not determined. We have characterized strains from Thailand into three races based on their interactions with susceptible and resistant soybean cultivars and have demonstrated the presence of a multifunctional member of the avrBs3/pthA family, avrXg1, and provide evidence that it also is carried on plasmid DNA.

The avrBs3/pthA gene family was originally identified in $X$. axonopodis pv. vesicatoria (7) and is now known to play diverse roles in interactions between Xanthomonas spp. and plants. They share unique structural features, including an N-terminal secretion signal peptide essential for delivery via the bacterial TTSS; a central repeat region consisting of 1.5 to 28.8 nearly identical tandem repeats of 34 or 35 amino acids; and a C-terminal region consisting of imperfect heptad leucine zipper (LZ) repeats, NLSs, and AAD (34). All of these regions affect function of the effectors in plant cells. For example, the highly conserved central repeat region determines host-specific pathogenicity and avirulence functions and may interact with conserved targets in diverse host species $(23,48)$. As indicated, the number of repeats in avrBs3 genes varies considerably between bacterial species $(6,7,9$, 16,42,50). In addition, AvrBs3 requires a functional NLS for transport into the nucleus of the plant cell (23). Some avirulence effectors such as AvrXa7 from X. oryzae pv. oryzae also require an AAD domain for virulence (48). The deduced protein encoded by $a v r X g 1$ is typical of the Xanthomonas avrBs3/pthA family members. It has a central domain containing a series of 20.5 copies of 102-bp direct repeats, three NLSs, and an AAD in the C-terminal region $(7,12,45,53)$.

It has been demonstrated that avr genes may have diverse functions that contribute to additive fitness and increased growth of the pathogen, sometimes resulting in increased disease on susceptible host plants $(8,47)$. Inactivation of $a v r B s 3 / p t h A$ genes by mutation generally results in loss of avirulence but also may lead to reduced virulence and growth rate in the host plant (47). Deletion of four repeats of avrBs3 in X. axonopodis pv. vesicatoria resulted in loss of recognition by receptor protein $B s 3$ in pepper cultivars carrying $B s 3$ with gain of recognition in pepper cultivars carrying $b s 3$. Deletion of the region between NLS2 and NLS3 (37 amino acids) as well as that between NLS1 and NLS3 (83 amino acids) of avrBs3 in $X$. axonopodis pv. vesicatoria resulted in complete loss of activity (45). Mutation in the hssB3.0 gene in $X$. axonopodis pv. citri resulted in increased aggressivness on Citrus grandis cv. Otachibana (38). Also, pthA isolated from $X$. axonopodis pv. citri confers an enhanced ability to induce cankers in the related $X$. axonopodis pv. citrumelo (47). Mutations in $a v r B s 2$ were shown to alter both virulence and avirulence in $X$. axonopodis pv. vesicatoria. Mutation of avrb6 in X. axonopodis pv. malvacearum did not affect bacterial growth in planta but was involved as a virulence factor in the production of water-soaking symptoms and the release of greater numbers of bacteria to the leaf surface (47). We provide evidence that mutation of the central repeat and C-terminal regions of $a v r X g l$ affects cultivar-specific responses. The requirement of the NLS and AAD for both hypertrophy induction and disease resistance is consistent with a 
role of AvrBs3 as transcriptional activator in the host nucleus (45). Our results indicate that the central repeat regions of $a v r X g 1$ are important for recognition by the Williams 82 receptor and that the C-terminal ADD domain is also required, presumably for virulence $(14,15)$. In addition to virulence, we show that avrXgl affects increased establishment of bacterial population in soybean leaves.
avrXgl was also expressed in $X$. axonopodis pv. glycines race 1 and race 2 strains. Race 1 normally causes HR on susceptible and resistant soybean cultivars but does not appear to carry avrBs3 homologous genes. Therefore, we predict that the HR induced by race 1 is nonspecific, similar to that associated with harpins and presence of $x a g P$ in several strains of $X$. axonopodis pv. glycines. Interestingly, expression of $\operatorname{avrXgl}$ in race 1 resulted in disease
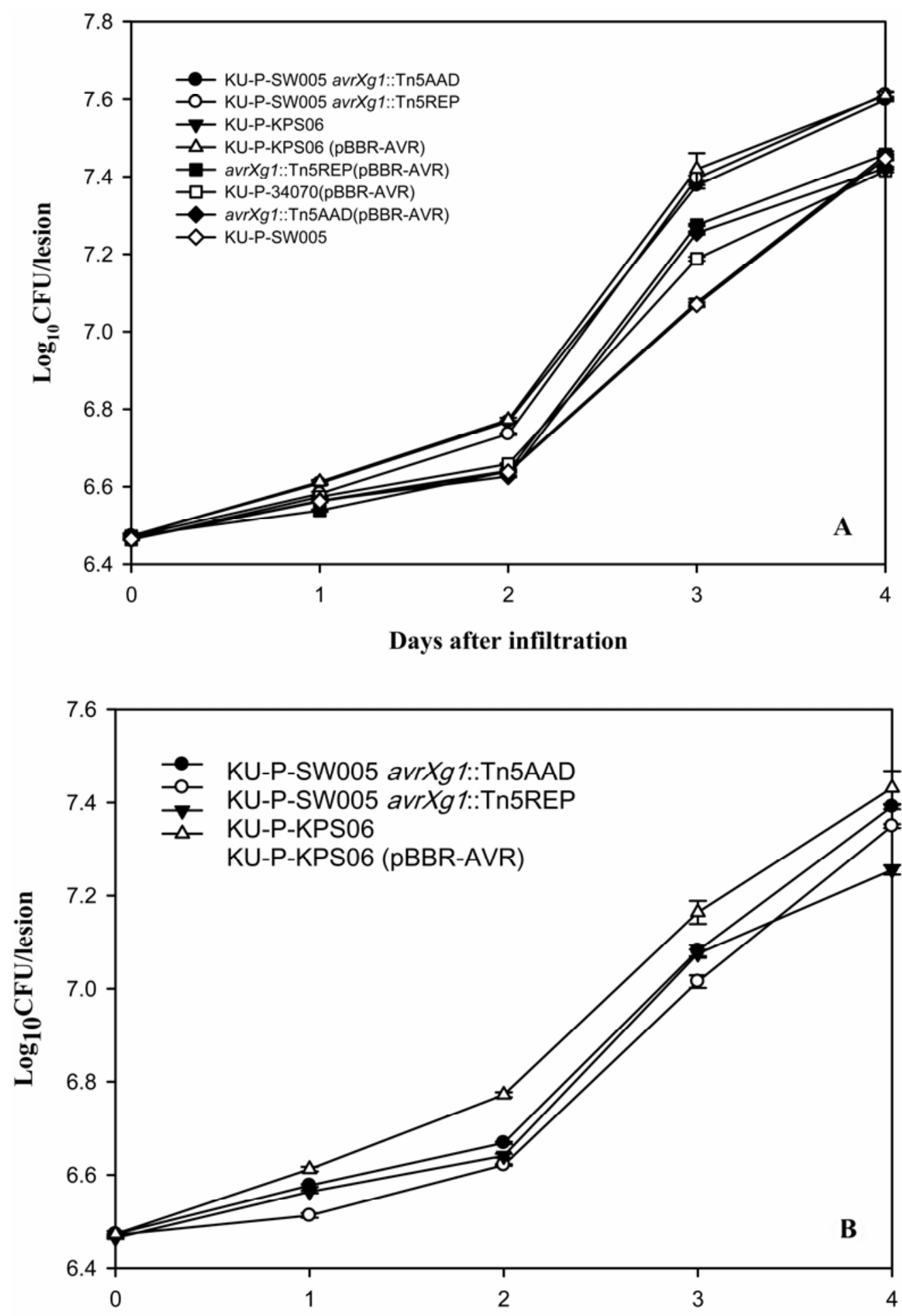

Days after infiltration

Fig. 3. Time course of bacterial growth in leaves of soybean A, Spencer and B, Williams 82 . Leaves were sampled 1, 2, 3, and 4 days after infiltration. For Spencer, KU-P-34070 caused a hypersensitive reaction (HR) and viable cells were undetectable in leaves within 48 h. For Williams 82, KU-P-SW005, KU-P34070, avrXg1::Tn5AAD (pBBR-AVR), avrXg1::Tn5REP (pBBR-AVR), and KU-P-34070 (pBBR-AVR) caused HR and were undetectable within 48 h. Data represent means from three repetitions, and vertical bars represent standard errors. 
formation on susceptible cvs. Spencer and PI 520733 and HR on Williams 82, thereby suppressing nonspecific HR in the susceptible but not in resistant cultivars $(1,11)$. Further research on interactions of the AvrXg1 in these cultivars is needed to clarify further this interesting interaction demonstrating the multiple functions that Avr proteins can have in plants.

Race 2 of $X$. axonopodis pv. glycines caused disease on resistant and susceptible cultivars. PCR analyses indicated the presence of $a v r B s 3$ homologous genes in race 2; however, their sequence and function are yet to be determined. Additional research is required to determine the specific protein structure of avrBs3 open reading frames in race 2 and how they compare with the protein encoded by $a v r X g 1$. Expression of $a v r X g 1$ in race 2 led to increased virulence and fitness, another phenotype attributed to $a v r$ genes in other bacteria $(4,24,47)$.

Several bacterial $a v r$ genes have been shown to contribute to virulence on susceptible plants lacking the corresponding $R$ gene. The mechanisms by which $a v r$ genes promote parasitism and disease, however, are not well understood (8). Ritter and Dangl (33) reported that avrRpt 2 of $P$. syringae may promote pathogenesis and interfere with induction of avrRpml/Rpml-mediated resistance. Chen et al. (8) provided a hypothesis for avrRpt 2 function promotion of virulence via two different mechanisms. The first states that avrRpt2 interferes with host defense and results in complete inhibition of resistance. The second involves modification or inhibition of a common component of the defense response rather than interfering specifically with known $R$-genemediated resistance, and results in an increase in growth of $P$. syringae pv. tomato strain DC3000. We have also shown that, in the absence of a functional $\operatorname{rxp}, \operatorname{avrXgl}$ functions to promote virulence and bacterial populations of $X$. axonopodis pv. glycines on susceptible Spencer. Therefore, $a v r X g 1$ should be added to the list of $a v r$ genes that also function as virulence (vir) factors on susceptible hosts lacking the corresponding $R$ gene $(18,33,37)$.

avrXgl was discovered and its functional domains were successfully identified based on its ability to confer avirulence on cv. Williams 82 carrying a predicted $R$ gene for bacterial pustule resistance. Further characterization of other avr genes in $X$. axonopodis pv. glycines and subsequent specific receptors in soybean will provide further insight into mechanisms of virulence and plant defense and will lead to development of useful methods for pustule disease control.

\section{ACKNOWLEDGMENTS}

This work was supported by a Royal Golden Jubilee Ph.D. scholarship from the Thailand Research Fund. We thank A. Thamchaipenet and C. Jompuk for kind recommendations; R. L. Nelson for providing soybean seed; and H. C. Hoch, P. Zaini, C. Reid, D. Zheng, S. Kaewnum, and J. A. Burr for providing technical assistance at the New York State Agricultural Experiment Station (NYSAES), Cornell University (Geneva, NY).

\section{LITERATURE CITED}

1. Abramovitch, R. B., and Martin, G. B. 2004. Strategies used by bacterial pathogens to suppress plant defenses. Curr. Opin. Plant Biol. 7:356-364. not cited in text

2. Alfano, J. R., and Collmer, A. 1996. Bacterial pathogens in plants: Life up against the wall. Plant Cell 8:1683-1698.

3. Alfano, J. R., and Collmer, A. 2004. Type III secretion system effector proteins: Double agents in bacterial disease and plant defense. Annu. Rev. Phytopathol. 42:385-414. not cited in text

4. Bai, J., Choi, S.-H., Ponciano, G., Leung, H., and Leach, J. E. 2000. Xanthomonas oryzae pv. oryzae avirulence genes contribute differently and specifically to pathogen aggressiveness. Mol. Plant-Microbe Interact. 13:1322-1329.

5. Barras, F., van Gijisegem, F., and Chatterjee, A. K. 1994. Extracellular enzymes and pathogenesis of soft rot Erwinia. Annu. Rev. Phytopathol. 32:201-234.

6. Bonas, U., Conrads-Strauch, J., and Balbo, I. 1993. Resistance in tomato to Xanthomonas campestris pv. vesicatoria is determined by alleles of the pepper-specific avirulence gene avrBs3. Mol. Gen. Genet. 238:261-269.

7. Bonas, U., Stall, R. E., and Staskawicz, B. J. 1989. Genetic and structural characterization of the avirulence gene avrBs3 from Xanthomonas campestris pv. vesicatoria. Mol. Gen. Genet. 218:127-136.

8. Chen, Z., Kloek, A. P., Boch, J., Katagiri, F., and Kunkel, B. N. 2000. The Pseudomonas syringae avrRpt2 gene product promotes pathogen virulence from inside plant cells. Mol. Plant-Microbe Interact. 13:13121321.

9. De Feyter, R., Yang, Y., and Gabriel, D. W. 1993. Gene-for-genes interactions between cotton $R$ genes and Xanthomonas campestris pv. malvacearum avr genes. Mol. Plant-Microbe Interact. 6:225-237.

10. Flor, H. H. 1942. Inheritance of pathogenicity of Melampsora lini. Phytopathology 32:653-669.

11. Fujikawa, T., Ishihara, H., Leach, J. E., and Tsuyumu, S. 2006. Suppression of defense response in plants by the avrBs3/pthA gene family of Xanthomonas spp. Mol. Plant-Microbe Interact. 19:342-349.

12. Gabriel, D. W. 1999. The Xanthomonas avr/pth gene family. Pages 39-55 in: Plant-Microbe Interaction, vol. 4. G. Stacey and N. T. Keen, eds. American Phytopathological Society Press, St. Paul, MN.

13. Goradia, L., Hartman, G. L., and Daniel, S. L. 2004. Pathogenicity of Xanthomonas axonopodis pv. glycines, the causative agent of bacterial pustule in soybeans. American Society for Microbiology.

14. Grant, S. R., Fisher, E. J., Chang, J. H., Mole, B. M., and Dangle, J. L. 2006. Subturfuge and manipulation: type III effector proteins of phytopathogenic bacteria. Annu. Rev. Microbiol. 60:425-449.

15. Gurlebeck, D. C., Thieme, F., and Bonas, U. 2006. Type III effector proteins from plant pathogen Xanthomonas and their roe in the interaction with the host plant. J. Plant Physiol. 163:233-255.

16. Hopkins, C. M., White, F. F., Choi, S.-H., Guo, A., and Leach, J. E. 1992. Identification of a family of avirulence genes from Xanthomonas oryzae pv. oryzae. Mol. Plant-Microbe. Interact. 5:451-459.

17. Hwang, I., and Lim, S. M. 1998. Pathogenic variability in isolates of Xanthomonas campestris pv. glycines. Korean J. Plant Pathol. 14:19-22.

18. Jackson, R. W., Athanassopoulos, E., Tsiamis, G., Mansfield, J. W., Sema, A., Arnold, D. L., Gibbon, M. J., Murillo, J., Taylor, J. D., and Vivian, A. 1999. Identification of a pathogenicity island, which contains genes for virulence and avirulence, on a large native plasmid in the bean pathogen Pseudomonas syringae pv. phaseolicola. Proc. Natl. Acad. Sci. USA 96:10875-10880.

19. Kaewnum, S., Prathuangwong, S., and Burr, T. J. 2005. Aggressiveness of Xanthomonas axonopodis pv. glycines isolates to soybean and hypersensitivity responses by other plants. Plant Pathol. 54:409-415.

20. Kaewnum, S., Prathuangwong, S., and Burr, T. J. 2006. A pectate lyase homolog, xagP, in Xanthomonas axonopodis pv. glycines is associated with hypersensitive response induction on tobacco. Phytopathology 96:1230-1236.

21. Kanamori, H., and Tsuyumu, S. 1998. Comparison of nucleotide sequences of canker-forming and non-canker-forming pthA homologues in Xanthomonas campestris pv. citri. Ann. Phytopathol. Soc. Jpn. 64:462470 .

22. Kanazin, V., Marek, L. F., and Shoemaker, R. C. 1996. Resistance gene analogs are conserved and clustered in soybean. Proc. Natl. Acad. Sci. USA 93:11746-11750.

23. Kay, S., Hahn, S., Marois, E., Hause, G., and Bonas, U. 2007. A bacterial effector acts as a plant transcription factor and induces a cell size regulator. Science 318:648-651.

24. Kearney, B., and Staskawicz, B. J. 1990. Wildespread distribution and fitness contribution of Xanthomonas campestris avirulence gene avrBs 2 . Nature 346:385-386.

25. Kim, J. G., Choi, S.-H., Oh, J., Moon, J. S., and Hwang, I. 2006. Comparative analysis of three indigenous plasmids from Xanthomonas axonopodis pv. glycines. Plasmid 56:79-87.

26. Kim, J. G., Jeon, E., Oh, J., Moon, J. S., and Hwang, I. 2004. Mutational analysis of Xanthomonas harpin $\mathrm{HpaG}$ identifies a key functional region that elicit the hypersensitive response in nonhost plants. J. Bacteriol. 186:6239-6247.

27. Kim, J. G., Park, B. K., Yoo, C. H., Jeon, E., Oh, J., and Hwang, I. 2003. Characterization of the Xanthomonas axonopodis pv. glycines Hrp pathogenicity island. J. Bacteriol. 185:3155-3166.

28. Kovach, E. M., Elzer, P. H., Hill, D. S., Robertson, G. T., Farris, M. A., Roop II, R. M., and Peterson, K. M. 1995. Four new derivatives of the broad-host-range cloning vector pBBR1MSC, carrying different antibiotic-resistance cassettes. Gene 166:175-176.

29. Park, H. J., Han, S. W., Oh, C., Lee, S., Ra, D., Lee, S. H., and Heu, S. 2008. Avirulence gene diversity of Xanthomonas axonopodis pv. glycines isolated in Korea. J. Microbial. Biotecnol. 18(9):1500-1509.

30. Pirhonen, M. U., Lidell, M. C., Rowley, D. L., Lee, S. W., Jin, S., Liang, Y., Silverstone, S., Keen, N. T., and Hutcheson, S. W. 1996. Phenotypic expression of Pseudomonas syringae avr genes in E. coli is linked to the activities of the hrp-encoded secretion system. Mol. Plant-Microbe 
Interact. 9:252-260.

31. Prathuangwong, S., and Amnuaykit, K. 1989. Studies on tolerance and rate reducing bacterial pustule of soybean cultivars/lines. Kasetsart J. 21:408-420.

32. Prathuangwong, S., and Khandej, K. 1998. An artificial inoculation method of soybean seed with Xanthomonas campestris pv. glycines for inducing disease expression. Kasetsart J. 32:84-89.

33. Ritter, C., and Dangl, J. L. 1996. Interference between two specific pathogen recognition events mediated by distinct plant disease resistance genes. Plant Cell 8:251-257.

34. Saijo, Y., and Paul, S. L. 2008. Manipulation of the eukaryotic transcriptional machinery by bacterial pathogens. Cell Host Microbe 4:96-99.

35. Saisangthong, S. 1999. Fingerprint genome of Xanthomonas campestris pv. glycines strain by using random amplified polymorphic DNA (RAPD) assay. M.S. Thesis, Kasetsart University, Bangkok, Thailand.

36. Sambrook, J., Fritsch, E. F., and Maniatis, T. 1989. Molecular Cloning: A laboratory Manual, 2nd ed. Cold Spring Harbor Laboratory Press, Cold Spring Harbor, NY.

37. Shan, L., He, P., Zhou, J., and Tang, X. 2000. A cluster of mutations disturb the avirulence but not the virulence function of AvrPto. Mol. Plant-Microbe Interact. 13:592-598.

38. Shiotani, H., Fujikawa, T., Ishihara, H., Tsuyumu, S., and Ozaki, K. 2007. A pthA homolog from Xanthomonas axonopodis pv. citri responsible for host-specific suppression of virulence. J. Bacteriol. 189:3271-3279.

39. Shiotani, H., Tsuyumu, S., and Ozaki, K. 2000. Pathogenic interactions between Xanthomonas axonopodis pv. citri and cultivars of pummelo (Citrus grandis). Phytopathology 90:1383-1389.

40. Staskawicz, B. J., Dahlbeck, D., and Keen, N. T. 1984. Cloned avirulence gene of Pseudomonas syringae pv. glycinea determines race-specific incompatibility on Glycine $\max$ (L.) Merr. Proc. Natl. Acad. Sci. USA 81:6024-6028.

41. Staskawicz, B., Dahlbeck, D., Keen, N., and Napoli, C. 1987. Molecular characterization of cloned avirulence gene from race 0 and race 1 of Pseudomonas syringae pv. glycinea. J. Bacteriol. 169:5789-5794.
42. Swarup, S., Yang, Y., Kingsley, M. T., and Gabriel, D. W. 1992. A Xanthomonas citri pathogenicity gene, pthA, pleiotropically encodes gratuitous avirulence on nonhosts. Mol. Plant-Microbe Interact. 5:204-213.

43. Tusanasarit, K. 1995. Effects of planting date, spacing, nitrogen source and irrigation rate on severity of soybean bacterial pustule. M.S. Thesis, Kasetasrt University, Bangkok, Thailand.

44. Van, K., Kim, D. H., Cai, C. M., Kim, M. Y., Shin, J. H., Graham, M. A., Shoemaker, R. C., Choi, B.-S., Yang, T.-J., and Lee, S.-H. 2008. Sequence level analysis of recently duplicated regions in soybean [Glycine $\max (\mathrm{L}$. Merr.] genome. DNA Res. 15:93-102.

45. Van den Ackerveken, G., Marois, E., and Bonas, U. 1996. Recognition of the bacterial avirulence protein AvrBs3 occurs inside the host plant cell. Cell 87:1307-1316.

46. Vauterin, L., Hoste, B., Kersters, K., and Swings, J. 1995. Reclassification of Xanthomonas. Int. J. Syst. Bacteriol. 45:472-489.

47. Vivian, A., and Gibbon, M. J. 1997. Avirulence genes in plant-pathogenic bacteria: signals or weapons? Microbiology 143:693-704.

48. White, F. F., Yang, B., and Johnson, B. L. 2000. Prospects for understanding avirulence gene function. Plant Biol. 3:291-298.

49. White, T. J., and Gonzalez, C. F. 1995. Electroporation of Xanthomonas. Pages 135-141 in: Methods in Molecular Biology, Vol. 47. J. A. Nickoloff, ed. Humana Press Inc., Tutowa, NY.

50. Wu, X. M., Li, Y. R., Zou, L. F., and Chen, G. Y. 2007. Gene-for-gene relationships between rice and diverse avrBs3/pthA avirulence genes in pv. oryzae. Plant Pathol. 56:26-34.

51. Yang, B., and White, F. F. 2004. Diverse members of the AvrBs3/PthA family of type III effectors are major virulence determinants in bacterial blight disease of rice. Mol. Plant-Microbe Interact. 17:1192-1200.

52. Yang, Y., Yuan, Q., and Gabriel, D. W. 1996. Watersoaking function(s) of $\mathrm{XcmH} 1005$ are redundantly encoded by members of the Xanthomonas avr/pth gene family. Mol. Plant-Microbe Interact. 9:105-113.

53. Zhu, W., Yang, B., Chittoor, J. M., Johnson, L. B., and White, F. F. 1998. AvrXa10 contains an acidic transcriptional activation domain in the functionally conserved C terminus. Mol. Plant-Microbe Interact. 11:824832 . 